\title{
Price Control of Local Foodstuffs in Kumasi,
Ghana, 1979
}

\author{
Gracia Clark
}

University of Michigan

\section{INTRODUCTION}

Price control and related commercial issues have been among the most controversial national political issues in Ghana. Debates and accusations concerning price control enforcement and the acceptable or actual role of traders have been used to justify the rise and fall of national governments. Successive military and civilian governments in Ghana since independence have faced rising prices, especially of imports and manufactures, which critics attributed to their soft or corrupt tactics in price control. Each new government then legitimised itself with an initial episode of strict enforcement, which tapered off and gave rise to new accusations. Price control thus plays a particularly prominent role here in the processes of state formation and regime stabilization.

The Armed Forces Revolutionary Council (AFRC), which brought Flight Lieutenant J. J. Rawlings to power on June 4, 1979, claimed that Lt. Col. Akuffo, who had ousted

longstanding head of state Gen. Acheampong the year before, had not gone far enough in punishing those who had benefited from corruption. Akuffo had made arrests and ordered a strict enforcement episode shortly after taking office, but enforcement had already relaxed considerably. Declarations on price control were among the earliest proclamations of the AFRC, the day after the coup.

Rawlings considered at that point that corruption could be cured by removing corrupt individuals from the existing system. During its short term of office (June to October, 1979), the AFRC carried out what it called a "housecleaning exercise" directed at government officials, private formal sector enterprises and market traders. The first targets were those involved in illegal distribution of imports (see C. Robertson, 1983). Although official price control regulations did not 


\section{Price Control in Ghana}

include local foodstuffs, enforcement was extended to them several weeks later, without an immediate legal basis.

This paper describes that exercise, its extension and its

effects on Kumasi food supplies, along with traders' responses,

For comparison, it also briefly describes their responses to the currency exchange exercise carried out under Akuffo earlier the same year and its effects. Although the AFRC repeatedly stated that the housecleaning exercise was not aimed at punishing the ordinary market trader, but only the middlemen and women, it damaged her more deeply and permanently than the currency exchange.

Detailed analysis of a specific encounter between traders and the state makes it easier to get beyond the presentation of either side as an undifferentiated unit in such encounters. Specific groups wielding some authority from the state, including police, soldiers, local and national government officials and traditional leaders, each had their own interests and patterns of action within the overall situation. Traders' responses also reveal critical subdivisions within their ranks, by commodity, gender, trading role and capital level, which determined both their motivation and capacity for specific responses.

The actions and reactions of these predominantly female, Asante traders show the necessity of analysing women not simply in relation to their household status, but in relation to their work status, as for male traders or wage workers. These women were wives and mothers, and in many cases their family financial responsibilities motivated their trading activities, but their commercial relations were largely distinct from household relations. Few worked in kin-based trading networks like those described for Accra Ga women (C.

Robertson, 1984). Commercial relations were not extensions of family and marital relations, although Asante women also considered the latter extremely important. The tendency in many West African cultures for spouses and close kin to have separate budgets and even to avoid joint economic enterprises may partly explain this separation of work and household identities (C. Robertson 1983, p.483; Clark, 1984).

Trading roles identified with Asante women were historically constructed as gendered relations in themselves, as much so as the roles of wife and mother. As for family and marital roles, this continuing process of reproduction and reconstruction of trading roles involves both class-type economic differentiation and state intervention. The articulation of family with occupational relations is in fact an important aspect of differentiation for both men and women (Clark, 1988). 
Attention to this process of the historical construction of both traders and the state itself sheds light on the course of events and on their impact. Gender, ethnic, commodity and trading role divisions among traders specify their history of confrontation and collusion with the state, and with specific agents of the state. All of those characteristics have been significant to state relations for traders (and also for other occupational groups, such as farmers), and continue to be significant in the present case.

\section{HISTORY OF PRICE CONTROL}

A long history of intervention in trade, including price formation, by colonial and pre-colonial rulers (explored in detail in Clark, n.d.(b)) gave these efforts at food price control wide local acceptance. Although import and export controls were most frequent, controls were repeatedly extended to local crops in times of crisis. The studies collected recently by Guyer (1987) show that concern for and intervention in urban food supply systems by both colonial and chiefly authorities, although not always effective, was by no means a rare phenomenon in Africa.

In nineteenth century Asante, the Asantehene ${ }^{2}$ taxed and regulated trade in foodstuffs with neighboring chiefdoms. During public crises, he might control local food prices, requisition food for government needs, and embargo specific neighbors (Wilks, 1975; Brown 1972). The British colonial government similarly intervened during both World Wars to maintain adequate, low-cost food supplies for major cities, mines, barracks, and other government needs, although with limited success. In Asante, food prices were only set for Kumasi (the regional capital) and a few mining centers, and proved largely unenforceable. Import prices also were frequently ignored or officially raised (NAK3,7,13).

Ideological initiatives of the colonial power complemented price lists, arrests and requisitions. Colonial officials blamed rising food prices and falling real wages on supposedly parasitic market women, who were strongly defended by nationalist leaders, including Danquah (NAA4,5,6). While opposing food price controls, nationalist leaders pressed strongly for controlled prices of imports in a direct and rather sophisticated attack on the worsening terms of trade. One of the earliest nationalist actions, the 1938 cocoa hcldup, also sprang from this awareness and resentment of oligopolistic commercial relations and worsening terms of trade. 
Upon independence, the Convention People's Party government, led by Kwame Nkrumah, followed up on both colonial and nationalist agendas. It expanded controls over imports, especially the popular consumer items on the list of "essential commodities." This list included moderately priced consumer imports and local manufactures, such as evaporated milk, canned fish, toothpaste and toilet paper, as well as "African print" cloth.

Faced with high inflation and worsening terms of trade, government propagandists adopted the colonial rhetoric of blaming market women, despite Nkrumah's debt to their support in the independence struggle. Price controls and currency regulations applied only to imported and

manufactured commodities, but public distribution agencies like the Ghana Food Distribution Corporation (GFDC) tried to undermine traders' control of local foodstuffs circulation as well. The notable failure of the GFDC to capture a significant percentage of the foodstuffs trade testifies to the complexity and value of the distributive tasks performed by the market traders, which public employees were unable to assume. 3

Trading patterns for imports and local manufactures especially those officially designated "essential commodities," adjusted during the 1960s and 70s to the reality of import and price controls. The cycle of episodes of strict enforcement (often in November) followed by periods of toleration for illegal trading had become routine by 1979 . Traders with family or corrupt connections to police, customs or legal distributors had a greater advantage than before. In the seller's market created by acute shortages of these goods, such connections were more essential to enterprise viability than business acumen or effort.

The adjustment process widened existing gaps between traders defined by family background and by capital level, and made these correspond more closely to commodity divisions. Traders in essential commodities who lacked the official connections and capital resources to survive enforcement episodes had either gone bankrupt or switched to local foodstuffs and craft products by this time. Some individuals reported switching because of psychological exhaustion from the stress of raids, arrests and confiscations, as Smart reports for Hong Kong traders leaving illegal locations (J.Smart). The extension of price controls to local foodstuffs and craft products during the 1979 "housecleaning exercise" thus not only hit those traders with the least resources to survive such attacks, but hit numerous traders who had moved into local foodstuffs trading precisely to avoid such episodes. 


\section{THE AFRC "HOUSECLEANING EXERCISE"}

\section{The Initial Campaign}

The AFRC began by punishing those who had offended against existing price and import controls on essential commodities. Their first target was the Makola \#1 Market in Accra, renowned as the premier marketplace in the country for wholesaling imported and manufactured items, including cloth. This was looted the day of the coup, closed down, and eventually blown up by dynamite (C. Robertson, 1983). Although it was the seat of wholesaling, Makola \#1 also included many retailers and traders in unregulated goods.

In Kumasi, price control enforcement also began with traders in imports and manufactures. The day after the coup, military officers in Kumasi entered the main Kumasi Central Market and sold off the stocks of traders in the provisions section at control prices. Sometimes the proceeds were given to the trader, sometimes they were kept for the "government chest." On the next day, soldiers broke open stalls in the adjacent cloth section and sold off the cloth, or confiscated it Owners of confiscated goods could go to the barracks later, if they dared, to bargain with the soldiers about the "control" value which they would be paid. After they finished. a mob that had collected to buy cloth and watch the proceedings crossed the street to loot stalls in the main lorry park.

The same day, soidiers took over the major formal sector stores downtown, moving down each street in turn. They sold out their stocks completely, including many items not covered by existing price controls. Since there was no official price, soldiers set prices on the spot, at one-fourth to one-tenth the commercial price. Searches of the homes of prominent store managers, former officials and Lebanese yielded further stores of hoarded goods, which were confiscated and taken to the barracks. Seized stores or government outlets were used to sell confiscated goods from various sources. There was a even brief glut of soft drinks from confiscated supplies. Within two or three weeks, such supplies ran out, and the stores stood empty.

A high level of street violence in Kumasi, as well as other parts of the country, continued for several weeks after the coup. Turbulent crowds roamed the streets, carrying large sums of money, ready to run for a place in line when a store suddenly began selling something. Standing in line brought injuries, either from belts and nightsticks of the attending soldiers, or from the free-for-alls that erupted once sales began. Shortages of staple foodstuffs like plantain and cassava led to 
long lines in their parts of the market. which also broke down into fights.

Official and semi-official violence reached levels unknown since the days of party politics. Price control offenders were officially beaten, caned and flogged naked and unofficially shaved with broken bottles. One was shot. Rumors circulated about women who had miscarried or had babies beaten to death on their backs. Traders who had taken previous economic losses philosophically became obsessed with repeating these stories of beatings and humiliations.

The rhetoric of official attacks on traders combined accusations of abuses of their middleman position with a generous dose of sexual hostility, analysed in more detail elsewhere (C. Robertson 1983; Clark n.d.(b)). Resentment among educated, salaried workers, hard hit by rampant inflation, of the disappearing (or reversing) gap between their incomes and those of uneducated relatives (including almost all women) also fed the flames. Media statements whipping up public outrage that even a few illiterate women could become as wealthy and powerful as some educated men created a climate that illegitimised any attempt to preserve traders' economic or consultative rights.

As Robertson comments,-the enthusiastic endorsement of condemnations of women traders by wide segments of the Ghanaian population was surprising, considering that most of that population had close female relatives in trade (C.

Robertson, 1983). Kinship ideals that presume separate financial and personal interests between husband and wife and between other household members may have made such attitudes easier to adopt, since spouse or kin do not necessarily see a woman's success as a benefit to them. The only public defenses of market women portrayed them as impoverished, helpless mothers, rather than as respected social actors. The message was clear: women traders could be tolerated as long as they remained powerless and unsuccessful.

These enforcement activities for non-food items had a negative impact on food sales in the market. Many foodstuffs traders, along with most other Kumasi residents with any money in their pockets, abandoned their work to stand in long lines for bargains on not only canned milk and mackerel, but freezers, mattresses, televisions and electric fans. Rumors that soldiers would soon come to the produce sections of the market encouraged more traders to stay away from the market if they could afford it. Villagers nervous about the general violence and thievery stayed away from Kumasi, with their goods.

Serious food shortages developed in Kumasi and other major cities immediately after the coup, although the 
government took no direct action against local foodstuffs traders for the first two weeks. Large cities and institutions like hospitals suffered the most, since they depended most on centrally purchased supplies. For more than a month, it was difficult in Kumasi for a household to locate enough traditional foodstuffs for meals, regardless of price. Mothers told of coming to Kumasi Central Market and crying, because they could find nothing to buy for the family. Urban residents quickly realised that they were more dependent on the rural areas than rice versa. When possible, families sent their children and other unemployed members to stay with rural relatives until food supplies improved. Newspapers considered the price and supply of food in different towns a major news item for the entire AFRC period.

\section{Food Price Control}

The AFRC began food price control very gingerly. First, they called for voluntary restraint and repeated empty assurances of physical safety in the towns. They began to enforce price control on the day of the national elections, June 18. Most traders and customers alike had taken the day off to go to the polls. The authorities even took the trouble to send female police that first day. They sold off the small stocks of the traders present in the yam, tomato and plantain sections, allowing the traders to collect the money, and warned others to reduce their prices. Since no control prices existed for these goods, they simply reduced existing prices by half. To control lines they used the "female" method of throwing buckets of water, rather than the belts and nightsticks commonly used by male police or the guns brandished by male soldiers. No traders were assaulted or goods confiscated.

Price control brought chaos to the wholesale yards the next day. Arriving traders who had begun to unload their yams threw them back into the trucks and drove away when they heard the news. Villagers arriving in the lorry park also simply turned around and went home with their produce. Armed soldiers began to patrol the wholesale yards, supervising forced sales from the trucks, and make forays into the foodstuffs "lines". The lack of known legal prices prevented effective cooperation with the soldiers. If traders set a low price, hoping to avoid trouble, the soldiers simply halved it again.

Several traders expressed the view that soldiers were mainly interested in getting food for their own consumption rather than enforcing low prices. Soldiers often took goods away without any compensation, telling an oil seller, for 
example, to come to the barracks in two weeks for her empty containers. Even when they sold the goods immediately, they made their own purchases first. With foodstuffs so scarce, this could exhaust the supplies available, even on July 12, almost a month later.

Setting official "control" prices for local foodstuffs presented immense practical problems, because of the wide variations in size, quality and condition characteristic of most popular foodstuffs. Price bargaining over individual units normally compensates for these variations. Standard prices for many foodstuffs cannot be widely publicised, understood and applied, because it remains unclear exactly what goods they apply to. When the first price lists came out, on June 23rd, they used units like kilos, not common in retail sales, and made no allowance for size, quality, distance from the producing region, or seasonal scarcity. The enforcement of uniform prices for chickens, for example, removed the premium for well-developed specimens. Soon only immature, small birds were for sale. The same happened with plantain, which was largely sold before maturity, if sold at all.

When foodstuffs stopped coming to Kumasi and other large towns, soldiers expanded their activities to major village periodic markets. Soldiers stationed nearby would visit these markets on the market day, confiscating goods in the possession of villagers or traders for sale at reduced prices or for use at the barracks. Villagers taking goods to sell at local periodic markets might find them purchased by the military at control price, although villagers did not usually suffer the physical abuse that traders did. Traders were conspicuous targets if they bought in wholesale quantities or transported goods on the roads, so they were afraid to visit the markets. The few

Kumasi traders who still ventured to their usual markets at this time reported that villagers stayed away from them, so they gave up the effort.

Farmers even avoided the informal sales locations established at highway or farm trail intersections. Those who still wanted to sell would take a small quantity of goods and walk along the roadside. If soldiers questioned them, they could claim they were carrying it home from the farm for family consumption. Hitherto this strategy had only been used by suppliers of imports.

When even the village markets largely emptied of goods, soldiers and other enforcement personnel began to "hijack" trucks. Soldiers from more remote barracks, without the advantage of access to a major market, would lie in wait on the major highways leading to Kumasi and intercept passing trucks, confiscating whole truckloads of produce. Town-based 
soldiers also captured trucks entering the outskirts of town. This tactic could only be loosely linked to price control enforcement, since the goods had not yet been offered for sale at any specific price, nor had they been hoarded. These truckloads were occasionally sold retail at control prices on the spot, but more often they were taken off to a nearby barracks. Not only freight trucks but mixed passenger/freight trucks were taken. Even a single bag or basket of produce could be considered evidence of intent to resell and confiscated under threat of arrest.

\section{Effects on Supplies and Prices}

Despite the energy devoted to these drastic actions, they did not achieve the desired effect of securing low-cost, plentiful urban food supplies. Farmers overwhelmingly responded by keeping their produce off the market. Traders themselves cannot hoard food supplies, because limited space, poor facilities and rapid spoilage prevent them from storing significant amounts (C. Robertson, 1983, p.480; see Clark, n.d.(a), for

more detail). Enforcement efforts directed at traders thus could not release extra food to consumers, even temporarily.

Farmers' ability to delay crop sales depended on the perishability of their specific crops, leading to uneven food shortages in Kumasi. Semi-perishable staples such as yams and corn were stored on the farm as long as possible. The AFRC came to power in June, before the yam harvest. Farmers normally begin taking early yams from their plants in July, to catch the high early prices. In 1979, they delayed harvesting for months, as long as December, until they needed to prepare the fields for replanting. Some still stored their yams in pits on the farm for several months afterwards. Likewise, some corn was normally sold green, as an early treat before the new yams. In 1979, farmers left it all to mature.

Perishable vegetables like tomatoes and garden eggs could not be harvested later. They came back on the market fairly quickly, but in smaller quantities than normal for that season. Cassava, though highly perishable once harvested, can be left in the ground for long periods without deterioration. It is planted on less desirable land than yams, so consequently disappeared from the market entirely until all danger was past. Ironically, food price control enforcement raised effective food prices above their previous level due to trade moving to clandestine locations, as well as from absolute urban shortages. Under normal conditions, Kumasi buyers and sellers enjoy a high level of information on supply, demand and prices paid Visual inspection of goods and prices offered is the most 
common information source. Price uniformity results from these publicly available high information levels, and never indicates prices set unilaterally by either side. Constant price variations between transactions compensate for size and quality variations, but also for fluctuating supply and demand during the day. The narrow price range lowers the risk for transactors, a major reason buyers and sellers patronise Kumasi Central Market. The low risk levels further lower prices, since they allow sellers to reduce their risk cushions. Commodities with higher risk levels also show wider price fluctuations.

Good information flows extend to peripheral trading areas. Wholesale buyers from Kumasi Central Market wholesale yards regularly checked nearby informal locations, such as the lorry parks, for lower prices. Their knowledge of relative prices helps prevent artificially raised prices in the foodstuffs wholesale yards, since they are ready to buy elsewhere without delay. Likewise, when price control artificially lowered prices in the yards, these peripheral locations could and did rapidly expand the volume of produce they handled. Though effective, their role was short-lived because soldiers immediately expanded their activities to the well-known peripheral areas when goods vanished from the wholesale yards

What food arrived in Kumasi after the markets emptied was sold at dawn from the backs of trucks in shifting roadside locations passed by word of mouth. When sales moved to street corners, back alleys, disused gas stations and vacant lots, prices were more variable, but averaged higher. Furtive, hurried, dispersed sales drastically reduce price information levels, because it is difficult and dangerous to compare prices from different sources. Competition between sellers was greatly reduced by shortages, since buyers knew they might not find another source of the item they needed. Prices also rose simply from the great reductions in supply, and the higher risk margin needed to induce sellers to participate. A negligible amount of foodstuffs was ever sold to the public at control price.

\section{Hunger and Capital Position}

This economic disruption widened the gap between urban residents, including traders, with some cash reserves and those with none. During the enforced idleness, traders with any capital had to use it to meet subsistence needs. Market porters and the poorer traders who sold on commission or on credit suffered great hardship immediately, because they depended on each day or week's proceeds to buy food. Most traders had so little capital in hand that they could not hold out for the length 
of this crisis. They either had to return to trading under dangerous, unprofitable conditions or go without food, usually both.

Coping strategies which had developed to see traders through seasonal shortages or individual crises such as illness or capital loss could not work now, due to the broad impact of this crisis. Many traders routinely adjusted to seasonal supply problems by switching to unaffected commodities or to craft work. Price control affected so many commodities that none were left to substitute. A surprising number of foodstuffs traders, including some who had previously fled cloth or provisions trading, began selling ice water, the most inoffensive (and unprofitable) item imaginable. Even they met with occasional rough treatment from soldiers. Craft alternatives like sewing or baking had also come to a standstill, due to lack of supplies and customers. Asking for emergency loans from trading partners or non-trading relatives or neighbors, a common strategy in individual catastrophes, was useless now, since they faced similar problems.

In fact, almost all economic activity ceased in Kumasi, between standing in lines, fear and lack of supplies. Possession of goods in normal working quantities for either trade or production brought punishment for hoarding. Drastic policy swings, usually retroactive, were so unpredictable that members of almost any occupation felt it might suddenly become illegal. Buying power was so affected that the demand for food was substantially reduced when controls were eventually relaxed and supplies returned.

Rural families with acute cash needs suffered along with poor urban families from the interruption in crop sales. Many farmers had committed their resources to specialised commercial food production to the extent that they depended on crop sales to finance purchase of other foods. Farm families also needed cash to cover school fees, medical expenses and other crises. These problems hit poorer farmers harder, since they had little cash or food reserves. The low-volume, high-risk conditions of trade made it difficult for farmers to find buyers in case of emergency, and lowered the prices the few remaining traders were willing to offer.

\section{Ideological Basis}

The AFRC justified its hostility to traders by emphasizing the economic advantages of direct sales from farmers to consumers. Traders supposedly forced prices up by frustrating this natural mechanism. Contrary to this model, direct sales are never very attractive to farmers, because of the farming 
days they lose in locating transport, selling their goods, and returning home. They were even more reluctant to make the trip to the city under these violent and unsettled conditions, nor was there much for them to buy there. Occasionally, military trucks were sent to buy farm produce or sell consumer goods in rural areas, but very little direct sales took place despite official exhortations. Lack of response to similar efforts in Peru suggests that economic realities, rather than fear of violence, are the determining factors on this issue (Babb, this volume). Ghanaian farmers found it more attractive to hold goods off the market, if at all possible, than cooperate with direct sales.

Realising the insecurity of their access to urban markets, farmers in more remote regions reverted to a more

subsistence-oriented planting pattern, at least temporarily. The price control experience weakened rural confidence in the food distribution system and in commercialisation itself. It led to some return to subsistence farming, especially in remote areas already facing interruptions in commercial contact because of transport problems. After all, farmers complained, they had nothing to buy with the money they earned, since legal supplies of imports rarely reached the rural areas. The money itself might be again declared obsolete, as in the currency exchange exercise earlier in 1979. Both long and short-term effects on farmers thus lowered urban food supplies.

While armed enforcement proved capable of seriously disrupting and damaging the existing food distribution system, it proved incapable of substituting for it. Under conditions of strict enforcement, a government implicitly claims that the official or legal distribution system can supply all of the recognised needs of the population. As the AFRC period wore on with no increase in urban staple food supplies, these claims lost credibility and food price control was quietly loosened. The Asantehene's police occasionally made rounds to encourage low prices, but they approached the traders involved quietly and carried no arms or nightsticks. It was left to the later Provisional National Defence Council (PNDC) government (1982-4) to make serious attempts to set up an alternative foodstuffs distribution network linking farmers to urban and institutional buyers.

\section{Demolitions}

As the date for handover to civilian rule approached, the AFRC turned to a series of demolitions to make a lasting mark on the nation's marketplace system. A few days after the demolition of Makola \#1, on September 5th, markets in 
regional capitals, including Kumasi, were destroyed. Like Makola \#1, Kumasi Central Market was a regional center of imports distribution. Unlike Makola \#1, however, it was also the city's only wholesale market for most local foodstuffs. Rumors claimed that Kumasi City Council members only narrowly managed to avert plans to demolish the entire Kumasi Central Market, on this basis.

The demolition episode displayed divisions between different parts of the state apparatus. City Council opposition may have reflected the major contribution of market fees and rents to the city budget. The Market Manager claimed to have had no advance warning. Like the most drastic price control enforcement, demolition was carried out by soldiers, who were less likely to have local origins. Police and the Asantehene's police had been noticeably more polite and less violent in previous actions, and took no part in this one.

To implement this policy successfully, the AFRC took advantage of internal divisions among traders by nationality, commodity and spatial location. Demolitions began at dawn, in a section that was marginal physically, organisationally and economically to the rest of the market, a n area of makeshift stalls at the rear of the market called the "French Line." Here, men from Northern Ghana and adjacent French-speaking countries sold shoes and other imported clothing, and reputedly changed currency through their commercial contacts. As for Makola \#1, complete demolition was supposedly required to uncover buried hoards of foreign currency.

First, soldiers surrounded this section to prevent removal of property. Soldiers with semi-automatic weapons rode the bulldozers as they razed the flimsy wooden stalls, while others searched and confiscated property. When the bulldozers had finished the French Line, however, they simply kept going, uprooting shade trees and levelling several small mosques and adjacent trading areas. Within two days, everything outside the old market walls had come down, about one-third of the total contiguous area administered as Kumasi Central Market. This comprised open areas where villagers sold their foodstuffs, several wholesale yards, and sections selling used clothing, craft goods and drugs. Ironically, the cloth and provisions sections, the Kumasi equivalent to Makola \#1, remained touched because they lay inside the walls.

Although outside the original market walls, these areas were official market locations. Traders using them were registered individually and paid rent to the city, in addition to their daily market fees. One factor in the amount of rent they paid was the size and elaboration of the structures they had erected, at their own expense but with city permission. Some 


\section{Price Control in Ghana}

sold from portable tables, while others had roofed stalls or enclosed, locking kiosks. Capital investment was not necessarily lower for these traders than for those within the market walls. The area housed some businesses based on valuable equipment--sewing machines, corn mills or chest freezers. Some traders had even recently received permission to expand their buildings or build new kiosks.

Market traders were given only a few hours notice, depending on their exact location in the path of the bulldozers, to remove or sell off their goods and salvage their equipment. Traders hurriedly arranged to store their inventory and equipment in nearby houses, or to transport it to their homes. Proprietors of a walk-in cold store that sold frozen fish and ice blocks to traders negotiated two days' grace to move out their freezer equipment. Owners of kiosks, designed to be movable either found someone to cart them away immediately or saw them demolished. Salvagers lingered to buy up the roofing sheets and lumber that were left.

As demolition progressed over two days, various

justifications for the policy from official spokesmen appeared in local newspapers or circulated through rumors. Most statements referred to it as a street clearance campaign supposed to provide for easy passage for pedestrians and supply trucks in the market precincts. The other expressed goals of tourist-oriented civic beautification and efficient, intensive land use seemed far-fetched, in view of the realities of Ghana's economic problems, although the same issues have some plausibility for the Indian, Hong Kong, and US cases elsewhere in this volume (Lessinger, A. Smart, and Spalter-Roth). In Kumasi, long-dormant plans for a clinic and "superhighway" on one side of the market were briefly resurrected, although cement and money were then unavailable even for construction projects already designed and half completed.

Only token efforts were made to keep demolished areas clear, showing that officials had little need to disguise the punitive nature of the clearance. Within a week, traders reoccupied the same areas they traded in before the clearance, with no further attempts to chase them away, and tax collection resumed. Traders sat in the same locations, selling the same commodities, but now they sat in the sun with their babies and their perishable vegetables instead of enjoying the meagre comfort of a roofing sheet or two. 


\section{TRADERS' RESPONSES}

\section{Price Control Negotiations}

Foodstuffs traders did have publicly recognised commodity groups and leaders, called ahemma, providing an organisational structure capable of rapid response to such crises. Group leaders' central functions were dispute settlement and negotiations with external bodies, not commercial regulation. Negotiating skills carry high prestige in Asante culture, and traders demand high skill levels from their leaders (Clark, 1984).

In contrast to $\mathrm{C}$. Robertson's report of passivity on the part of Accra market women (1983), the Kumasi ahemmafuo (collective plural) did respond quickly, requesting mediation from the city and regional officials and chiefs with whom they usually take up sensitive external issues. Soon these elderly and middle-aged women were complaining of an exhausting schedule of formal meetings and informal sessions initiated by themselves or others. It was startling to hear them complain in the same breath that the authorities did not want to negotiate.

Market ahemma claimed that "they don't want to talk"

despite incessant summons to meetings, because these meetings did not follow norms of legitimate "talking" as they knew them. Precisely because negotiations figure so prominently in Asante chiefly and marketplace ideals, traders have well-developed procedural norms and expect general respect for them. Proper dispute settlement procedures call for the full expression of all views before making a decision, and the agreement of all parties to the final settlement. A. Robertson confirms in a rural setting the importance of conforming to accepted, familiar meeting styles and procedures in order to ensure effective and recognized participation (A. Robertson 1976).

The AFRC broke these norms in several important ways. They ignored the definition of negotiations by scheduling thei "consultation" meetings after they had already made major decisions. During the meetings, opposing parties did not acknowledge points brought up by traders by agreeing or disagreeing, but simply repeated previous threats and exhortations. The authorities also failed to abide by agreements or promises made during meetings with traders.

For example, an attempt was made to establish standard size and quality grades for staple foodstuffs, to bring order to price control enforcement. The ahemmafuo brought samples of the major vegetable staples to the Ashanti Regional Offices. Under the sponsorship of the Regional Commissioner, they agreed with representatives of consumers, government buyers 
and the military on control prices for different sizes. In the next few days. however, soldiers in the market refused to recognize these prices or size grades and continued to set prices arbitrarily. The ahemma then counseled traders to stop buying from farmers unless they could obtain low enough prices to allow for this kind of sales.

The most elaborate meeting during this period led to the most resentment. Traders viewed both procedural and rhetorical features as insults to their leaders. Ahemma were not given a choice of time or place, but summoned to the meeting held in their own shed. The President and Secretary of the National Farmers' Association and a leader of the official farm laborer's association (all men) made no pretense of consultation or seeking mutual agreement. They harangued the traders about their stubborn refusal to lower prices, and threatened that traders would suffer for their evil ways. They completely ignored traders' counterclaims that farmers refused to sell at low prices. A particularly offensive speaker repeatedly asked "wati?" (lit. have you heard?), a phrase commonly used to instruct children or subordinates. One ohemma (sing.) complained, "They treat us like children. when we are old enough to be their mothers." During the meetings, the senior ohemma drew attention covertly to the fact that this meeting had no authority to decide anything by referring repeatedly and favorably to her ongoing negotiations with truck drivers over freight rates. In both sets of meetings,

participants commonly referred to each other as "the men" and "the women."

It is revealing to compare these meetings with price negotiations held during the same later months of the AFRC government with leaders of predominantly male occupations, to set control prices for their products. In each case,

representatives of suppliers of raw materials attended, and the prices of finished products and raw materials were set as a package. Producers of adinkra cloth, furniture and poultry linked their control prices to those of imported plain cloth, manufactured lumber, poultry feed and medicines. Meetings with drivers and transport owners likewise used control prices for gasoline, motor oil and spare parts to calculate legal passenger and freight rates.

Negotiations with male leaders did not produce exactly the desired results for either side, but procedures showed more respect. The resulting agreements were neither predetermined or ignored. Male leaders were not delegtimised for being group leaders, nor their followers for having specific occupational interests. These negotiated prices could not openly compensate for the necessity to buy supplemental supplies on the black 
market to stay in business, but the men used these meetings as a forum to press for larger allocations of foreign exchange for their imported supplies. Although the AFRC could not usually provide the level of supplies needed, they did abide by prices set at these meetings. These men were often idle from lack of legal supplies, or forced to resort to illegal supplies, but at least they were never harrassed for selling at the agreed prices.

\section{RESPONSES TO THE CURRENCY EXCHANGE}

The currency exchange exercise carried out in March, 1979. before the AFRC coup, provides another contrast. The AFRC government exerted itself to discredit market leaders and frustrate their attempts to help traders adjust to price control or circumvent it. Akuffo's government, althougli aiming the currency exchange partly against wealthy market traders, kep the official exchange procedures relatively straightforward and stable.

After closing all the borders, the government announced on Friday, March 9, that all existing banknotes would become valueless on March 26. The entire population had to exchange its old notes for new ones through the banks, at a rate of ten old to seven new cedis. Very large amounts would be exchanged at five new for ten old cedis, creating instant employment for thousands of poor persons who took the excess cedis of their wealthier relatives and neighbors for exchange. Although the deadline was extended another two weeks and extra facilities for exchange set up, the basic procedure remained the same. Individual capital losses varied arbitrarily, depending on the amount of capital in physical cash form that evening.

Market leaders' responses demonstrated their ability to expand their regulatory role temporarily in time of crisis, when left to manage their own adaptive processes. First they coordinated discussions of the procedures and practical implications of the exchange. This raised general information levels and formed a consensus on joint strategies for weathering the transition period. Leaders then publicised these decisions, so that individual traders would not suffer disproportionately. Kumasi traders and other urban dwellers suffered much less hardship than rural residents, who faced long journeys on scarce transport at exorbitant rates and waited for days at the few small-town banks, without new cedis for food or water.

In Kumasi Central Market, for example, commodity group relations helped traders decide how to respond. In the onion shed, onion traders met informally in the aisles Saturday 
morning to discuss the announcements. The ohemma collected information on procedures and rates of exchange and repeated it. One woman had brought a poster of the new money, which the ohemma showed around. The shed watchmen held their own conclave, which the ohemma visited. Some continued to do business at normal prices, as the government had instructed. As traders began to realize the old money had been effectively discounted, they stopped selling except for payment in coins. Individual retailers decided either to go home, or to adjust their prices and charge ten old cedis for seven in the original price.

The exchange announcement created havoc in commercial credit, especially in the wholesale yards, where large amounts were involved. Hysterical wholesalers sought advice from their ahemma when debtors tried to force payment in old notes. Travellers would not accept the old notes from wholesalers, since they expected farmers to reject them, but could not afford to stay in town indefinitely. In hardship cases, leaders negotiated reasonable discounts for the old notes. The cassava yard closed down when drivers doubled freight charges, only reopening as traders obtained new notes. The onion yard also closed in the second week, when traders decided to take a break to finish changing. Although the yards closed, the ahemma came to market daily to monitor conditions.

After the initial shock phase, commodity ahemma resumed a passive role. The level of commercial activity dropped to about half, since traders, drivers, suppliers and consumers all spent much of their time trying to exchange their money. Clients quarreled over who would receive the first few new notes when they began to appear. Although some appealed these cases to their ohemma, she could not settle them. Each trader had to decide which client was most valuable to her. Traders stated current sales prices either in new or old cedis, the latter prices climbing as the exchange deadline approached. Individual traders simply decided whether to accept old cedis or not, or to stay home. Some sellers extended credit rather than accept old notes. The ohemma could enforce these terms just like normal business agreements. A few traders with close bank connections continued accepting old cedis to the last day.

Wide fluctuations in food supply from day to day also raised ordinary commercial risks and tensions. Less perishable foodstuffs stopped arriving until sellers could demand new cedis, including cassava, dried fish and plantains. Crops that required frequent harvests, such as tomatoes, could not find enough buyers, especially with new cedis. Stress and hunger shortened tempers, and disputes in general multiplied.

Traders' responses were not effective in any absolute sense. They could not change the policy itself, or prevent capital losses 
severe enough to reduce the scale of operation of many

individuals. Only a handful of individual traders had either advance warning to deposit their cash, or close enough bank connections to circumvent exchange channels. However, traders' group actions did reduce or avoid the additional losses associated with commercial disruption, such as those during price control linked to suspension of normal information channels and dispute settlement procedures.

The reliance on individual strategies for exchange meant that this exercise, like price control, exacerbated tensions and disadvantages based on existing social stratification. Exchange procedures favored urban over rural residents, and those with elite connections over the marginal poor. As in provisions and cloth trading, corrupt individual relations proved more reliable than rational or industrious choices. Workers for large public or private employers could participate in special group exchange facilities not available to the self-employed.

Individual traders with some capital suffered losses, but could better survive the weeks of reduced activity than those dependent on daily or weekly receipts. The violent conditions of standing in line at banks, as for confiscated goods, favored strong, able-bodied young men over the elderly or weak, or mothers with babies on their backs.

\section{CONCLUSION}

Food price controls were exceptionally disruptive to distribution, both because of their novelty and because of official response to traders' adjustment efforts. Traders in imports and manufactures had already made their peace with episodic price control enforcement. Those without some political connections protecting them from prosecution and financial strength to survive periods of retreat had left the business years before. The AFRC brought simply a longer, more intense seige of the same tactics. Some individuals suffered great physical and financial damage, and many went out of business because of the length of their unemployment. but the system of distribution itself did not break down.

Trading in essential commodities was completely illegal, so open group negotiations were out of the question and former leaders had long since retired.

Although not completely unprecedented, government intervention in trade in local foodstuffs had never before been either widespread or effective. Food traders had no established strategies for dealing with it. Foodstuffs policies remained "new" for months, due to rapid, radical shifts in the prices and 
behavior subject to attack. Erratic and non-standardised enforcement compounded fluctuations and contradictions in announced offical policy. Each attempt by foodstuff traders to adjust to, compromise with, or evade price controls brought a change in enforcement tactics or policies, aimed at their new practices. The result was widespread demoralisation and hopelessness that persisted long after enforcement had ceased.

Government actions demonstrated hostility not only to

leaders of illegal activities, but to market leaders as such.

Foodstuffs commodity group leaders were ignored or humiliated in the negotiation processes already described. The mere existence of market groups and leaders was denounced in public announcements as evidence of traders' conspiracy to ruin the economy. The Asante chiefly hierarchy was recruited to attack their prestige by announcing they were not entitled to use the title ohemma, but could only be considered headmen. Market ahemma joked about their supposed sex change operations, but deeply resented the public insult by a hierarchy that had hitherto recognised them as leading members of the community on public occasions.

Comparison of the two policy crises points to the importance of market leaders in minimising both individual and group damage from hostile policies, even without formal recognition. Market leaders coordinated or facilitated traders individual responses to the currency exchange, rather than directing a group or collective response. This indirect role, when not actively frustrated, proved more effective than attempts at direct negotiations which found no sincere response.

More contradiction between ideology and practice emerged in the AFRC's relations with ordinary traders. The AFRC continually published statements claiming it was not against the small-scale trader or producer, even advising Makola traders to go into food selling, but actions and policies both belied this distinction. Not only did enforcement efforts concentrate on the more vulnerable, poorer traders, but other policy statements revealed an intent to eliminate food trading as such.

As in other economic sectors, the poorest traders bore the brunt of both direct military action and its economic side effects. Only a few foodstuffs traders were wealthy enough to consider buying protection or stopping altogether until the situation stabilised. Most lived on their daily or weekly income, and had to try some kind of economic activity. Those without capital to lose lost weight, paying in their health and strength.

Traders' loss of capital, through consumption or confiscation, had a devastating effect on commercial efficiency 
at both high and relatively low levels. Individuals able to buy in the minimum wholesale quantity found themselves buying in smaller quantities from intermediaries. Buyers who had filled a truck themselves in the supply areas now shared with others, waited for passenger transport, or fell to retailing. Considering the importance of Ghanaian markets in food distribution, these capital and efficiency losses were a serious blow to the national economy.

Paradoxically, the price control episode, supposedly not aimed at ordinary market traders, was much more devastating to them than the currency exchange, which included traders among its target groups. This fact suggests a very weakly

hidden agenda within the AFRC, of destroying the marketplace system as a power center in the economy resistant to government control (see also C. Robertson, 1983). This interpretation of underlying motives is consistent with historical trends in government commercial and regulatory

policies affecting markets from the colonial period onwards. As further confirmation, this agenda was later openly avowed in the early days of the PNDC government (1982), which included many of the same high level leaders, including Rawlings himself.

\section{NOTES}

1. These events were observed during a research project funded by the Overseas Development Administration (UK) in Kumasi from 1978-80. Of course, the opinions expressed here are those of the author, not the ODA. Mona Etienne, Estellie Smith, Karen Hansen, Jane Guyer, Marjorie Mbilinyi and Lillian Trager made valuable comments on earlier versions of the paper, not all of which I was able to incorporate.

2. The Asantehene is the ruler of the Asante confederacy, the largest political unit in present-day Ghana before British conquest in 1901. He retains substantial political, moral and ritual power throughout Asante, but especially in Kumasi, the capital. He supports a considerable staff and household,

drawing on state financial support and legal status as well as indigenous properties and payments.

3. Traders' productive contributions are discussed in greater detail by Claire Robertson (1983) and Florence Babb (1987). 
at both high and relatively low levels. Individuals able to buy in the minimum wholesale quantity found themselves buying in smaller quantities from intermediaries. Buyers who had filled a truck themselves in the supply areas now shared with others, waited for passenger transport, or fell to retailing. Considering the importance of Ghanaian markets in food distribution, these capital and efficiency losses were a serious blow to the national economy.

Paradoxically, the price control episode, supposedly not aimed at ordinary market traders, was much more devastating to them than the currency exchange, which included traders among its target groups. This fact suggests a very weakly hidden agenda within the AFRC, of destroying the marketplace system as a power center in the economy resistant to government control (see also C. Robertson, 1983). This interpretation of underlying motives is consistent with historical trends in government commercial and regulatory

policies affecting markets from the colonial period onwards. As further confirmation, this agenda was later openly avowed in the early days of the PNDC government (1982), which included many of the same high level leaders, including Rawlings himself.

\section{NOTES}

1. These events were observed during a reserach project funded by the Overseas Development Administration (UK) in Kumasi from 1978-80. Of course, the opinions expressed here are those of the author, not the ODA. Mona Etienne, Estellie Smith, Karen Hansen, Jane Guyer, Marjorie Mbilinyi and Lillian Trager made valuable comments on earlier versions of the paper, not all of which I was able to incorporate.

2. The Asantehene is the ruler of the Asante confederacy, the largest political unit in present-day Ghana before British conquest in 1901. He retains substantial political, moral and ritual power throughout Asante, but especially in Kumasi, the capital. He supports a considerable staff and household, drawing on state financial support and legal status as well as indigenous properties and payments.

3. Traders' productive contributions are discussed in greater detail by Claire Robertson (1983) and Florence Babb (1987). 


\section{REFERENCES}

Babb, Florence

1987 Marketers as Producers: The Labor Process and Proletarianization of Peruvian Market Women. In David Hakken and Johanna Lessinger, eds. Perspectives in US Marxist Anthropology. Boulder: Westview Press.

Brown, James W.

1972 Kumasi 1898-1923: Urban Africa During the Early Colonial Period. PhD thesis, Dept. History, University of Wisconsin, Madison, WI.

Clark, Gracia C.

1984 The Position of Asante Women Traders in Kumasi Central Market, Ghana. PhD thesis, Dept. Social Anthropology, University of Cambridge, UK.

1988 Money, Sex and Cooking: Manipulation of the Paid/Unpaid Boundary by Asante Market Women. In B. Orlove and H. Rutz, eds. The Social Economy of Consumption: Anthropological Approaches. Monographs in Economic Anthropology, No.6 Society for Economic Anthropology and University Press of America, Lanham, MD.

n.d.(a) Food Traders and Food Security, forthcoming in R E. Downs, D. O. Kerner and S. P. Reyna, eds. The Political Economy of African Famine: The Class and Gender Basis of Hunger. London: Gordon and Breach.

n.d.(b) The Political Economy of Price Control for Ghanaian Market Traders, forthcoming in E. Winans, ed. New Perspectives on African Political Economy. Seattle: University of Washington Press.

Guyer, Jane

1987 Feeding African Cities. London: International African Institute and Manchester University Press.

NAA (Ghana National Archives, Accra)

NAA4 No. 0866 ST17, Complaints against profiteering by trading firms. Anonymous letter to the Governor, $23 / 9 / 41$. 
NAA5 No. 0866 ST17, President of the Joint Provincial Councils to the Secretary for Native Affairs. $20 / 11 / 41$.

NAA6 No. 0028 SF8, Irregularities in Import Control. motion by Hon. Dr. J . B. Danquah, 26/3/47.

NAK (Ghana National Archives, Kumasi)

NAK3 No. 1136, Foodstuffs and Meat Regulation, item 63. Director of Agriculture to Chief Agricultural Officer, Kumasi, 2/9/41.

NAK7 No. 1315, item 44. Minutes of a Meeting of the Obuasi Sanitary Board Held on 18th July, 1941.

NAK13 No. 124, item 18. Report for the Period $1 \mathrm{st}$ April 1935--31st March 1936. Ashanti Division, Department of Agriculture, 27/4/36.

Robertson, A. F

1976 Rules, strategies and the development committee.

Community Development Journal 11:185.

Robertson, Claire

1983 The Death of Makola and Other Tragedies.

Canadian Journal of African Studies 17:469.

1984 Sharing the Same Bowl. Bloomington: Indiana University Press.

Wilks, Ivor

1975 Asante in the Nineteenth Century. Cambridge: Cambridge University Press. 